\title{
Discharge Plasma Treatment for NOx Reduction from Diesel Engine Exhaust: A Laboratory Investigation
}

\author{
B.S. Rajanikanth, A.D. Srinivasan and V. Ravi \\ Department of High Voltage Engineering \\ Indian Institute of Science \\ Bangalore 560012, India
}

\begin{abstract}
A detailed study on the removal of oxides of nitrogen $\left(\mathrm{NO}_{x}\right)$ with and without the presence of carbonaceous soot in a stationary diesel engine exhaust was carried out using pulsed electrical discharges/catalyst/adsorbent processes. The processes were separately studied first and then the cascaded processes namely plasmacatalyst and plasma-adsorbent were examined. To investigate the effect of carbonaceous soot on the plasma treatment process, the filtered and unfiltered exhaust was treated by plasma separately. In the cascaded plasma-catalyst process, the plasma treating filtered exhaust was cascaded with a reduction catalyst $\mathrm{V}_{2} \mathrm{O}_{5} / \mathrm{TiO}_{2}$ using ammonia as reducing agent and in the cascaded plasma-adsorbent process, the plasma treating unfiltered (raw) exhaust was cascaded with adsorbents (MS13X/Activated alumina/Activated charcoal). The enhanced NOx removal efficiency of plasma process in the presence of soot is identified, possible pathways are summarized and the results of the cascaded processes are discussed in detail.
\end{abstract}

Index Terms - Pulsed discharges, NOx removal, discharge plasma, non-thermal plasma, engine emission, raw exhaust, plasma-catalyst, plasma-adsorbent, particulate treatment, Stationary emission source.

\section{INTRODUCTION}

$\mathrm{R}_{\mathrm{a}}^{\mathrm{E}}$ EMOVAL of NOx from diesel exhaust has been a challenge to researchers, as many conventional techniques such as catalysis, exhaust gas recirculation and other engine design modifications have failed to bring down the level of NOx to mandatory limits put across various countries. In this context, electrical discharge plasma technique appears to be very promising [1]. Majority of the discharge-based studies were done using simulated pure gas mixtures and most of them were carried out at room temperatures. Though it is simpler to understand the detailed mechanisms and reaction pathways with simulated gas mixture treatment, it is very important to study the actual exhaust treatment using plasma reactor as the diesel exhaust consists of various components, which cannot simply be simulated using pure gases. Further, the diesel engine raw (unfiltered) exhaust contains more particulate matter as compared to petrol engine. The particulate matter present in the raw exhaust is comprised of dry carbon (soot) and volatile organic fraction (VOF), which is nothing but hydrocarbons (HC). Literature shows that the presence of hydrocarbons and carbonaceous soot in

Manuscript received on 2 March 2004, in final form 16 May 2004 diesel engine raw exhaust enhances the NOx removal efficiency, when the raw exhaust is treated with discharge plasma [2-4].

It has been established that electric discharge plasma alone cannot remove NOx from diesel exhaust $[5,6]$. This demands discharge plasma to be combined with other aftertreatment techniques. Literature is abound with many works with hybrid plasma techniques [7-12].

In this paper, the NOx removal studies were carried out for two cases. In the first case filtered diesel engine exhaust is treated with plasma and/or plasma assisted by a reduction catalyst. In the second case unfiltered diesel engine exhaust (raw exhaust) is treated with plasma and/or plasma-adsorbent technique. The effect of carbonaceous soot in enhancing the NOx removal efficiency in the second case is discussed further. In the experiments involving catalyst or adsorbent, the exhaust was filtered before entering the catalyst or adsorbent.

The studies were carried out at different temperatures for the filtered exhaust case and for the unfiltered exhaust case the temperature was maintained at room temperature. The filtered exhaust treatment was conducted at no load and at 50\% load, while the unfiltered exhaust treatment was conducted at no load condition. 


\section{EXPERIMENTAL SETUP}

The experimental setup is shown in Figures 1a and $1 b$. The details of the setup are given below.

\subsection{HIGH VOLTAGE PULSE SOURCE}

This consists of a $0-25 \mathrm{kV}$ high voltage ac system, a rectifier unit, a charging capacitor, a rotary spark gap (RSG) and the corona (plasma) as load. The hemispherical rotating electrode of the RSG was connected to a motor through an insulating rod. By changing the speed of the motor the frequency of the pulses applied to the plasma reactor can be controlled. Throughout the experiments, the frequency of the pulses was kept constant at 130 pulses per second (pps). The pulse voltage applied to the reactor was measured by means of a $150 \mathrm{MHz}$ digital oscilloscope (DL1540, $200 \mathrm{MS} / \mathrm{s}$, Yokogawa) connected through a 2000:1 voltage divider (EP-50K, $50 \mathrm{MHz}$, PEEC, Japan). The current was measured using a current probe (P6021, Tektronix) and the power was measured directly from the oscilloscope as the product of voltage and current waveforms.

\subsection{DIESEL EXHAUST SOURCE}

The diesel exhaust for the treatment was taken from a $4.4 \mathrm{~kW}$ diesel generator. The exhaust was treated under both no-load and 50\% load conditions. An electric heater was connected as a load to the engine for carrying out the experiments at load condition. A part of the exhaust gas was made to pass through the treatment zone and the gas flow rate in the treatment zone was maintained at 4 $\mathrm{L} /$ minute.

\subsection{PLASMA REACTOR (PR)}

A dielectric barrier discharge reactor (referred to as plasma reactor) was employed in the present studies. The plasma reactor was a cylindrical glass tube (inner diameter $15 \mathrm{~mm}$ and outer diameter $17 \mathrm{~mm}$ ) consisting of a stainless steel rod of thickness $1 \mathrm{~mm}$ as the inner electrode and aluminium foil wrapped over the glass tube as the outer electrode. The effective length of the reactor where discharge took place was $30 \mathrm{~cm}$. The experiments involving plasma reactor were carried out at temperatures of 24,100 and $150^{\circ} \mathrm{C}$. For this, the reactor was placed in an electric furnace whose temperature could be controlled according to the requirements.

\subsection{CATALYTIC REACTOR (CR)}

The catalyst used was a commercially available $\mathrm{V}_{2} \mathrm{O}_{5} / \mathrm{TiO}_{2}$ in the form of honeycomb (20 cells per square inch). The content of vanadium in the catalyst was $5 \mathrm{wt} \%$ and the apparent volume of the honeycomb was $31 \mathrm{~cm}^{3}$ $\left(1.8 \times 1.8 \times 9.7 \mathrm{~cm}^{3}\right)$. This honeycomb structure was inserted in a glass tube of $26 \mathrm{~mm}$ inner diameter and $30 \mathrm{~cm}$ length, which formed the catalytic reactor. The catalytic reactor was placed after the plasma reactor. Together, the combination is referred to as cascaded plasma-catalytic reactor. In this configuration, the plasma reactor was operated at room temperature whereas the catalytic reactor was operated at 100,150 and $200^{\circ} \mathrm{C}$.

\subsection{ADSORBENT REACTOR (AR)}

This is made of quartz glass tube of $15 \mathrm{~mm}$ diameter and effective length of $35 \mathrm{~cm}$ filled with the adsorbent beads such as activated charcoal/Molecular sieves MS13X/activated alumina. This reactor was kept at room temperature.

\subsection{FILTERING AND CONDITIONING SYSTEM (FCS)}

This consists of two oil mist filters, one solid particulate filter and a moisture separator (UF10 SS, Ultra Filter India Ltd, India). The exhaust gas coming out of this unit has dew point of $-23^{\circ} \mathrm{C}$ at atmospheric pressure. Proper care has been taken in the development of this conditioning system so as not to affect the sample gas components.

\subsection{FT-IR UNIT}

The measurement of NOx, $\mathrm{CO}$ and other gaseous pollutants present in the diesel engine exhaust gas was carried out accurately using a multicomponent FTIR gas analyzer (DX-4010, Temet Instruments, Finland). The FTIR uses the CALCMET software to compute the concentrations of the components present in the sample gas from the absorbance spectrum.

\section{RESULTS AND DISCUSSION}

A $4.4 \mathrm{~kW}$ diesel generator was used for the experiments. Initially, before taking any measurement with FTIR, zero calibration of FTIR was done by passing $\mathrm{N}_{2}$ gas. Before treating the exhaust gas the concentrations of $\mathrm{CO}$, total hydrocarbon (THC), NOx, $\mathrm{N}_{2} \mathrm{O}$ and aldehyde were measured. Table 1 shows the typical concentrations of the pollutants under no-load and $50 \%$ load conditions. In the table, NOx means sum of concentrations of $\mathrm{NO}$ and $\mathrm{NO}_{2}$. The concentrations of $\mathrm{NO}$ and $\mathrm{NO}_{2}$ were measured individually and then added to get the NOx concentration. The total hydrocarbons (THC) are the sum of various HCs present in the exhaust, which could be measured using

Table 1. Initial Concentrations of diesel engine exhaust components.

\begin{tabular}{ccc}
\hline Components & No load & $50 \%$ load \\
\hline $\mathrm{H}_{2} \mathrm{O}$ & $0.3 \mathrm{vol} \%$ & $0.3 \mathrm{vol} \%$ \\
$\mathrm{CO}_{2}$ & $2 \mathrm{vol} \%$ & $4 \mathrm{vol} \%$ \\
$\mathrm{O}_{2}$ & $11 \mathrm{vol} \%$ & $9 \mathrm{vol} \%$ \\
$\mathrm{CO}$ & $560 \mathrm{ppm}$ & $720 \mathrm{ppm}$ \\
$\mathrm{NOx}\left(\mathrm{NO}+\mathrm{NO}_{2}\right)$ & $250(210+40) \mathrm{ppm}$ & $710(620+90) \mathrm{ppm}$ \\
$\mathrm{THC}$ & $95 \mathrm{ppm}$ & $200 \mathrm{ppm}$ \\
Aldehydes & $40 \mathrm{ppm}$ & $75 \mathrm{ppm}$ \\
\hline
\end{tabular}




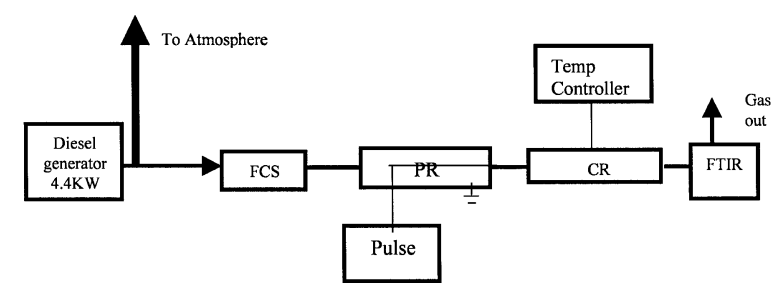

(a)

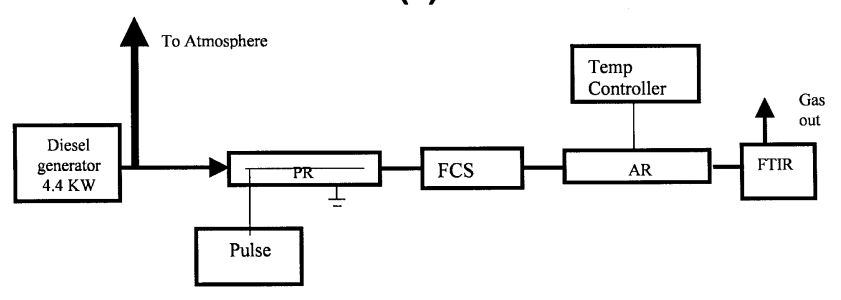

(b)

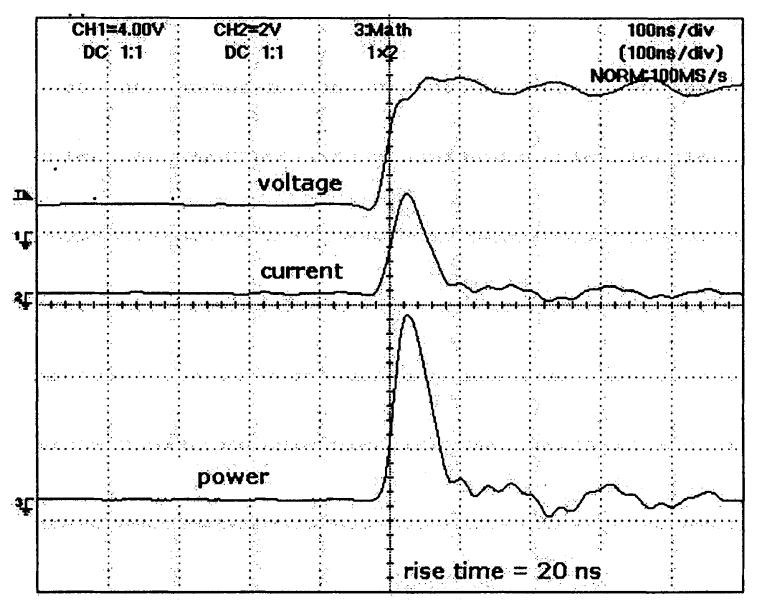

(c)

Figure 1. a, Experimental setup for diesel engine filtered exhaust treatment; b, Experimental setup for diesel engine unfiltered exhaust treatment; c, Waveforms of voltage, current and power. FCS, Filtering and conditioning system; PR, Plasma reactor; CR, Catalytic reactor AR, Adsorbent reactor.

FTIR analyzer. THC in the present study includes methane $\left(\mathrm{CH}_{4}\right)$, ethylene $\left(\mathrm{C}_{2} \mathrm{H}_{4}\right)$, acetylene $\left(\mathrm{C}_{2} \mathrm{H}_{2}\right)$, butane $\left(\mathrm{C}_{4} \mathrm{H}_{10}\right)$, propene $\left(\mathrm{C}_{3} \mathrm{H}_{6}\right)$, benzene $\left(\mathrm{C}_{6} \mathrm{H}_{6}\right)$, and toluene $\left(\mathrm{C}_{7} \mathrm{H}_{8}\right)$. Aldehydes included formaldehyde and acetaldehyde.

In the present paper, all the results were presented in terms of specific energy density. At first, the discharge energy per pulse was measured as the integration of the product of voltage and current waveforms as shown in Figure 1c. In the figure Trace1, Trace 2 and Trace 3 respectively refer to voltage, current and power. Multiplying the discharge energy per pulse by the pulse repetition rate gave the average discharge power. The energy density was calculated as the ratio of average discharge power to the gas flow rate. The results were first presented for the filtered exhaust case covering plasma technique and cas-

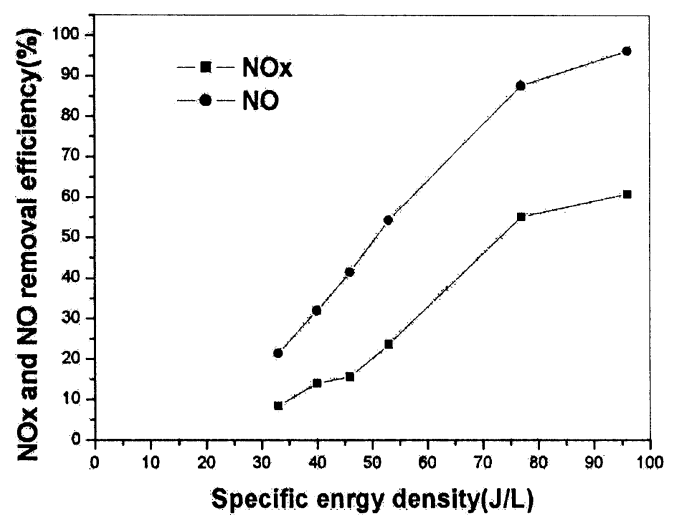

Figure 2. Variation of $\mathrm{NO}_{\mathrm{x}}$ and $\mathrm{NO}$ removal efficiencies with respect to specific energy density, in case of plasma reactor treating filtered exhaust at room temperature under no load condition.

caded plasma-catalytic technique, then the results were shown for the unfiltered (raw) exhaust case, discussing plasma, adsorbents and cascaded plasma-adsorbent techniques.

\subsection{FILTERED EXHAUST TREATMENT \\ 3.1.1 PLASMA REACTOR (PR) \\ 3.1.1.1 NOX/NO REMOVAL AT ROOM TEMPERATURE UNDER NO LOAD CONDITION}

Figure 2 shows the variation of NOx and NO removal efficiencies with respect to output specific energy density. Both NOx and NO removal efficiencies increase with increase in energy density. For instance, at an energy density of $66 \mathrm{~J} / \mathrm{L}, \mathrm{NOx}$ and NO removal efficiencies of 45 and $75 \%$, respectively are recorded. Possible reaction pathways responsible for NOx and NO removal can be summarized as below $[2,3,6,13,14]$.

NOx removal reactions

$\mathrm{N}_{2}+\mathrm{e} \rightarrow \mathrm{N}+\mathrm{N}+\mathrm{e}$

$\mathrm{NO}+\mathrm{N} \rightarrow \mathrm{N}_{2}+\mathrm{O}$

$\mathrm{CH}_{3} \mathrm{O}+\mathrm{NO} \rightarrow \mathrm{CH}_{3} \mathrm{ONO}$

$\mathrm{CH}_{3} \mathrm{O}+\mathrm{NO}_{2} \rightarrow \mathrm{CH}_{3} \mathrm{ONO}_{2}$

$\mathrm{CH}_{2} \mathrm{CHO}+\mathrm{NO} \rightarrow \mathrm{CH}_{2} \mathrm{CHONO}$

NO-NO $\mathrm{N}_{2}$ conversion reactions involving $\mathrm{O} / \mathrm{O}_{3}$ radicals

$\mathrm{O}_{2}+\mathrm{e} \rightarrow \mathrm{O}+\mathrm{O}+\mathrm{e}$

$\mathrm{NO}+\mathrm{O} \rightarrow \mathrm{NO}_{2}$

$\mathrm{O}_{2}+\mathrm{O} \rightarrow \mathrm{O}_{3}$

$\mathrm{NO}+\mathrm{O}_{3} \rightarrow \mathrm{NO}_{2}+\mathrm{O}_{2}$

NO-NO ${ }_{2}$ conversion reactions involving $\mathrm{HC}$ and $\mathrm{O}$ radicals

$\mathrm{O}+\mathrm{C}_{3} \mathrm{H}_{6} \rightarrow \mathrm{CH}_{2} \mathrm{CO}+\mathrm{CH}_{3}+\mathrm{H}$

$\mathrm{O}+\mathrm{C}_{3} \mathrm{H}_{6} \rightarrow \mathrm{C}_{2} \mathrm{H}_{5}+\mathrm{HCO}$

$\mathrm{O}+\mathrm{C}_{3} \mathrm{H}_{6} \rightarrow \mathrm{CH}_{3} \mathrm{CHCO}+\mathrm{H}+\mathrm{H}$ 


$$
\begin{aligned}
& \mathrm{HCO}+\mathrm{O}_{2} \rightarrow \mathrm{CO}+\mathrm{HO}_{2} \\
& \mathrm{H}+\mathrm{O}_{2} \rightarrow \mathrm{HO}_{2} \\
& \mathrm{HO}_{2}+\mathrm{NO} \rightarrow \mathrm{NO}_{2}+\mathrm{OH} \\
& \mathrm{C}_{3} \mathrm{H}_{6}+\mathrm{O} \rightarrow \mathrm{CH}_{2} \mathrm{CHO}+\mathrm{CH}_{3} \\
& \mathrm{CH}_{3}+\mathrm{O}_{2} \rightarrow \mathrm{CH}_{3} \mathrm{O}_{2} \\
& \mathrm{CH}_{3} \mathrm{O}_{2}+\mathrm{NO} \rightarrow \mathrm{NO}_{2}+\mathrm{CH}_{3} \mathrm{O} \\
& \mathrm{CH}_{3} \mathrm{O}+\mathrm{NO} \rightarrow \mathrm{HNO}_{2}+\mathrm{CH}_{2} \mathrm{O} \\
& \mathrm{HNO}+\mathrm{O}_{2} \rightarrow \mathrm{NO}_{2}+\mathrm{OH}
\end{aligned}
$$

$\mathrm{NO}-\mathrm{NO}_{2}$ conversion reactions involving $\mathrm{HC}$ and $\mathrm{OH}$ radical

$$
\begin{aligned}
& \mathrm{C}_{3} \mathrm{H}_{6}+\mathrm{OH} \rightarrow \mathrm{C}_{3} \mathrm{H}_{6} \mathrm{OH} \\
& \mathrm{C}_{3} \mathrm{H}_{6} \mathrm{OH}+\mathrm{O}_{2} \rightarrow \mathrm{C}_{3} \mathrm{H}_{6} \mathrm{OHOO} \\
& \mathrm{C}_{3} \mathrm{H}_{6} \mathrm{OHOO}+\mathrm{NO} \rightarrow \mathrm{C}_{3} \mathrm{H}_{6} \mathrm{OHO}+\mathrm{NO}_{2}
\end{aligned}
$$

Diesel exhaust being an oxygen rich exhaust, contains large number of $\mathrm{O}$ radicals which enable efficient oxidation of $\mathrm{NO}$ to $\mathrm{NO}_{2}$, thus making the plasma environment $\mathrm{NO}_{2}$ rich in case of filtered exhaust plasma treatment [1, 15]. NOx removal in this environment is favored mainly by methoxy radical induced reactions (3), (4) and (5) [14].

\subsubsection{EFFECT OF HIGHER EXHAUST TEMPERATURE AND ENGINE LOADING ON NOX/NO REMOVAL}

Figure 3 shows effect of exhaust temperature on NO removal efficiency under no load condition. With increase in output energy density, the NO removal increases at all exhaust temperatures and at a given energy density, the NO removal decreases with increase in exhaust temperature. At an energy density of $86 \mathrm{~J} / 1$, the NO removal efficiency at 24,100 and $150^{\circ} \mathrm{C}$ was 90,69 and $44 \%$, respectively. This indicates that, at high temperatures, more energy input is required to bring about high NO removal efficiencies. The decrease in NO removal efficiency with temperature can be attributed to the following:

(a) The rate coefficient of oxidation reaction (7) decreases with increase in temperature thereby reducing the efficiency of $\mathrm{NO}$ conversion to $\mathrm{NO}_{2}$.

(b) Depletion of ozone at increased temperature which otherwise plays an important role in NO oxidation (reaction 9).

(c) At increased temperature, the $\mathrm{NO}_{2}$ gets reduced back to $\mathrm{NO}\left(\mathrm{NO}_{2}+\mathrm{O} \rightarrow \mathrm{NO}+\mathrm{O}_{2}\right)$.

(d) Many hydrocarbons, which enhance the oxidation of NO at room temperature, may not do the same at increased temperatures. This is because, the rate coefficients of reactions involving the release of active hydrocarbon species decreases at increased temperatures [16].

The NO removal efficiencies at different temperatures for $50 \%$ load exhaust are shown in Figure 4. The room

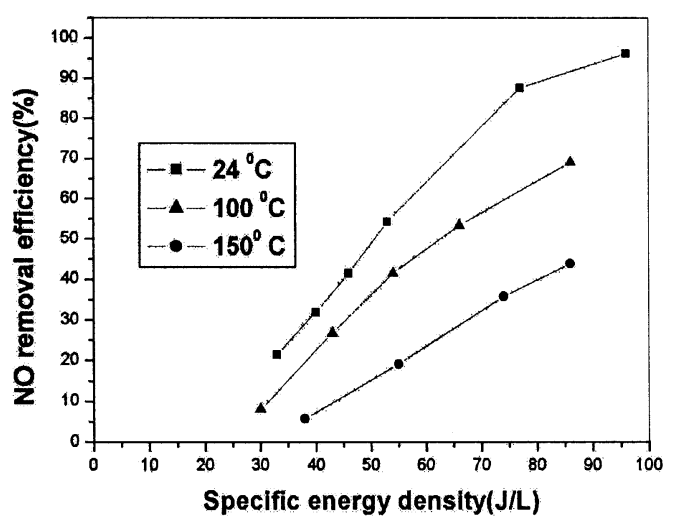

Figure 3. NO removal efficiencies at different exhaust temperatures in case of plasma reactor treating filtered exhaust under no load condition.

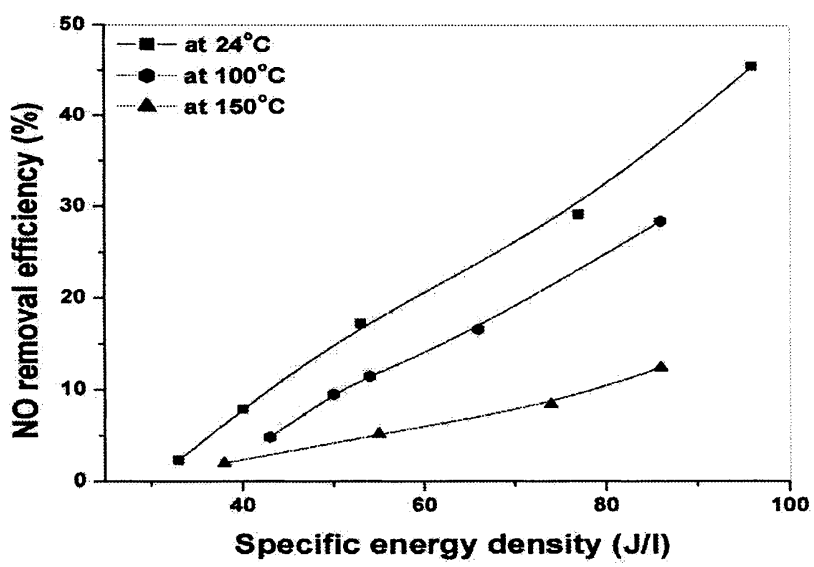

Figure 4. NO removal efficiencies at different exhaust temperatures in case of plasma reactor treating filtered exhaust under $50 \%$ load condition.

temperature treatment gave rise to maximum $\mathrm{NO}$ removal efficiency of $45 \%$. This value was less than half of the removal efficiency obtained when the exhaust was treated under no load conditions. This was because of high NO initial concentration under load condition (620 ppm). NO removal efficiency decreases with increase in initial concentration of NO [17]. For a given electric field, the number of radicals produced is constant. However, the ratio of active radicals with respect to NO molecules decreases with increase in initial NO concentration thereby decreasing the NO removal. Similar to the results obtained under no-load conditions, the NO removal efficiencies decreased at increased temperatures under load conditions. At temperatures, 100 and $150^{\circ} \mathrm{C}$ the $\mathrm{NO}$ removal efficiencies obtained were only 28 and $12 \%$, respectively.

Figure 5 shows the NOx removal efficiencies obtained at various temperatures when the exhaust was treated under no load conditions. At room temperature, at an energy density of $96 \mathrm{~J} / \mathrm{L}$, the NOx removal efficiency was $60 \%$, while at 100 and $150^{\circ} \mathrm{C}$, it was 33 and $21 \%$, respectively. The reason for this decrease was as explained in 


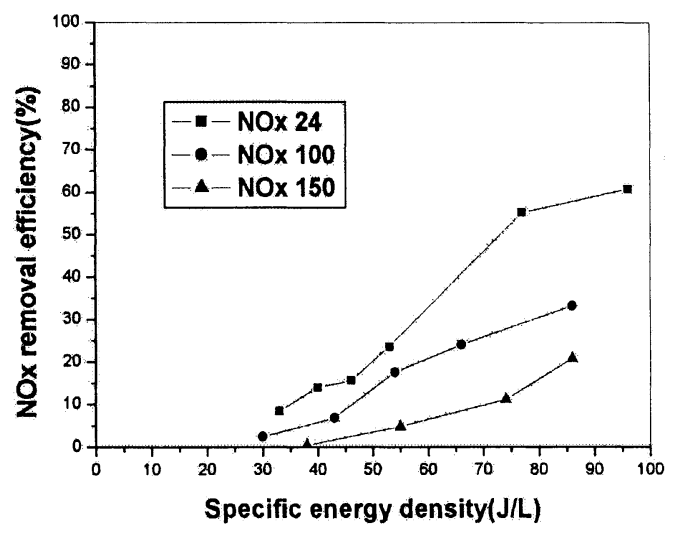

Figure 5. NOx removal efficiencies at different exhaust temperatures in case of plasma reactor treating filtered exhaust under no load condition.

the previous section. When the exhaust under $50 \%$ loads was treated, the NOx removal decreased further. At room temperature, the NOx concentration reduced to $535 \mathrm{ppm}$ from an initial concentration of $710 \mathrm{ppm}$. This amounted to a removal efficiency of $25 \%$. At 100 and $150^{\circ} \mathrm{C}$, the NOx removal efficiencies were 20 and $10 \%$, respectively.

\subsubsection{CASCADED PLASMA-CATALYTIC REACTOR (CPCR)}

The catalytic reactor, with $\mathrm{V}_{2} \mathrm{O}_{5} / \mathrm{TiO}_{2}$ as the catalyst, was placed after the plasma reactor. The catalyst $\mathrm{V}_{2} \mathrm{O}_{5} / \mathrm{TiO}_{2}$ is a SCR catalyst, which uses ammonia as its reducing agent. Ammonia was added in a ratio of 1:1 to NOx. In this system, the plasma reactor was operated always at room temperature whereas the catalytic reactor was operated at temperatures of 100,150 and $200^{\circ} \mathrm{C}$. The reason for operating plasma reactor at room temperature was that the NO removal efficiency obtained was very less at increased temperatures especially under no load conditions. As can be seen in the coming section, the NO removal $\left(\mathrm{NO}_{2}\right.$ production) using plasma reactor plays a very

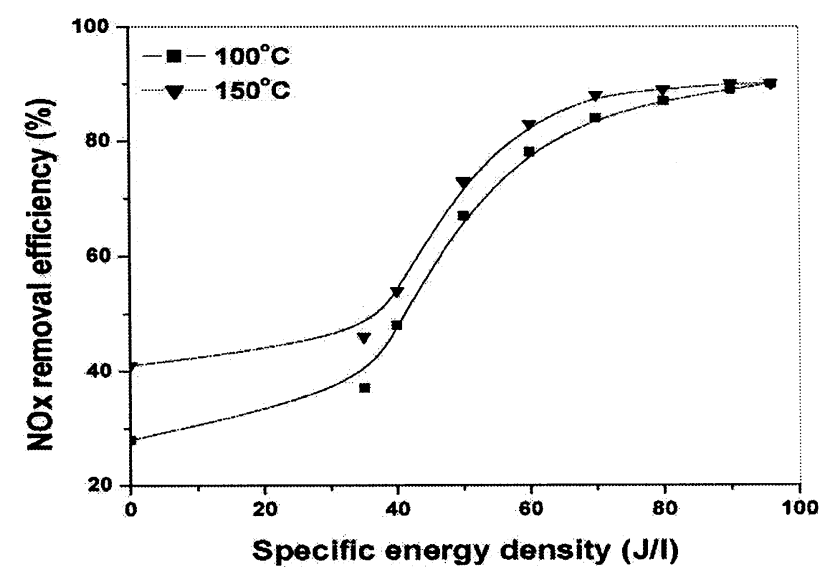

Figure 6. NOx removal efficiencies at different exhaust temperatures in case of cascaded plasma-catalytic reactor under no load condition.

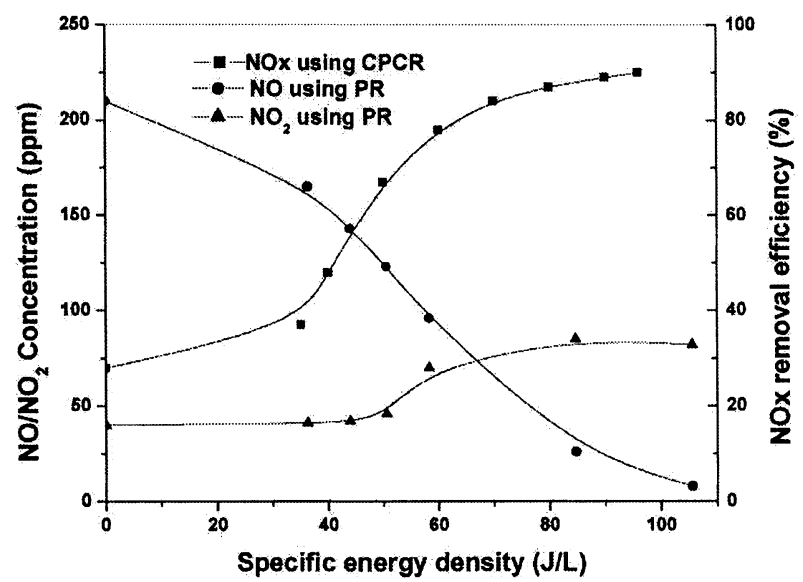

Figure 7. $\mathrm{NO}$ and $\mathrm{NO}_{2}$ concentrations obtained using $\mathrm{PR}$ along with the NOx removal efficiency obtained using CPCR under no load condition. $\mathrm{PR}$ at room temperature and $\mathrm{CPCR}$ at $100^{\circ} \mathrm{C}$.

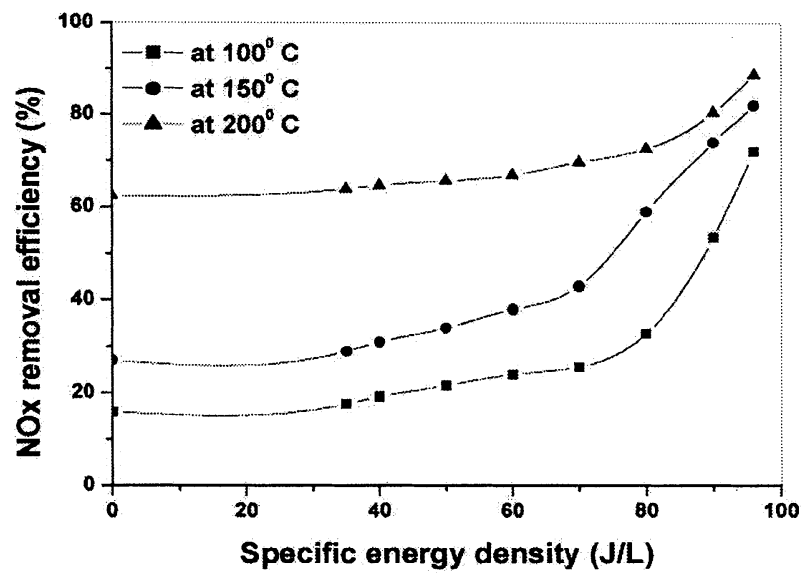

Figure 8. NOx removal efficiency at different exhaust temperatures in case of cascaded plasma-catalytic reactor under $50 \%$ load condition.

important role in helping the catalysis process to take place effectively even at temperatures below $200^{\circ} \mathrm{C}$. If hydrocarbons were added to the exhaust stream, the plasma reactor could be operated at temperatures above $24^{\circ} \mathrm{C}$ even under load conditions. However, in the present paper work, the hydrocarbons were not added.

In all the figures pertaining to CPCR (Figures 6-9), the zero energy input $(0 \mathrm{~J} / \mathrm{L})$ corresponds to the catalyst performance alone without plasma being operated. Individual figure is now being discussed. Figure 6 shows the NOx removal efficiencies obtained under no-load conditions of the exhaust. At $100^{\circ} \mathrm{C}$, the $\mathrm{CPCR}$ achieved a maximum NOx removal efficiency of $90 \%$. The performance of catalyst alone at $100^{\circ} \mathrm{C}$ in removing NOx was $27 \%$. As the energy input to plasma reactor increases, the NOx removal increases and reaches $84 \%$ at an energy density of $70 \mathrm{~J} / \mathrm{L}$. Beyond this energy input, the increase in NOx removal becomes slower and finally gets stabilized to $90 \%$ at $96 \mathrm{~J} / \mathrm{L}$. At $150^{\circ} \mathrm{C}$, similar trends were observed. The 


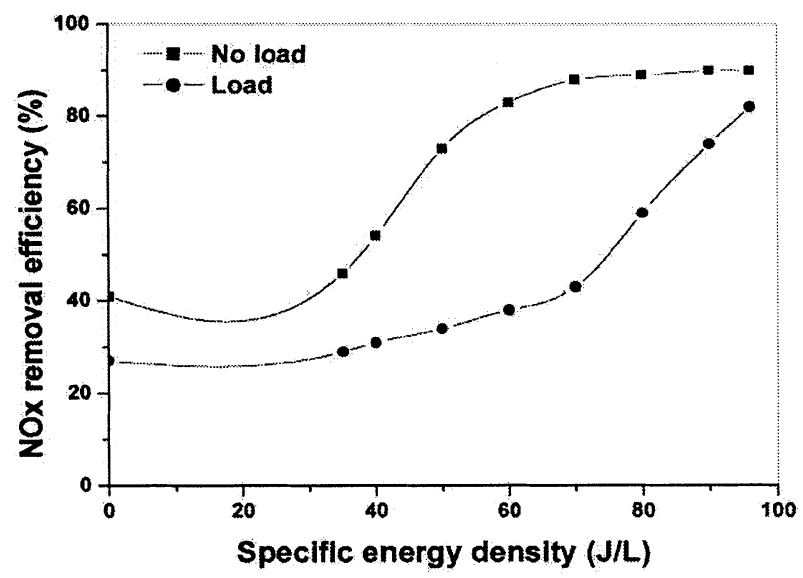

Figure 9. Comparison of NOx removal efficiencies in case of cascaded plasma-catalytic reactor under $50 \%$ load and no load conditions at an exhaust temperature of $150^{\circ} \mathrm{C}$.

maximum NOx removal achieved was same as that at $100^{\circ} \mathrm{C}$. The NOx removal efficiency at $200^{\circ} \mathrm{C}$ is not shown because the NOx removal by catalyst alone was $80 \%$ and that there was no necessity of combining it with plasma. The NOx removal using this CPCR system can be explained as below.

According to [18], the SCR catalysis is more pronounced when the NOx in the exhaust stream consists of equal amounts of $\mathrm{NO}$ and $\mathrm{NO}_{2}$. Since the plasma reactor oxidizes $\mathrm{NO}$ to $\mathrm{NO}_{2}$, the exhaust entering the catalytic reactor consists of both $\mathrm{NO}$ and $\mathrm{NO}_{2}$. With the increase in $\mathrm{NO}_{2}$ concentration entering the catalytic reactor, the NOx removal increases. Ammonia in presence of the catalyst reduces $\mathrm{NO}$ and $\mathrm{NO}_{2}$ mainly through the following reaction,

$4 \mathrm{NO}+4 \mathrm{NH}_{3}+\mathrm{O}_{2} \rightarrow 4 \mathrm{~N}_{2}+6 \mathrm{H}_{2} \mathrm{O}$

$6 \mathrm{NO}_{2}+8 \mathrm{NH}_{3} \rightarrow 7 \mathrm{~N}_{2}+12 \mathrm{H}_{2} \mathrm{O}$

Reaction (23) is known to take place at high temperatures such as above $200^{\circ} \mathrm{C}$ whereas reaction (24) can take place below $200^{\circ} \mathrm{C}$ also. The overall reaction can be represented as

$\mathrm{NO}+\mathrm{NO}_{2}+2 \mathrm{NH}_{3} \rightarrow 2 \mathrm{~N}_{2}+3 \mathrm{H}_{2} \mathrm{O}$

Figure 7 presents $\mathrm{NO}$ and $\mathrm{NO}_{2}$ concentrations obtained using PR along with the NOx removal efficiency obtained using CPCR, under no load condition. The concentrations of $\mathrm{NO}$ and $\mathrm{NO}_{2}$ at the outlet of the PR become equal for an energy input of around $60 \mathrm{~J} / \mathrm{L}$. It is observed that, the NOx removal efficiency obtained using CPCR at an energy density of $60 \mathrm{~J} / \mathrm{L}$ was very high suggesting that equal $\mathrm{NO}$ and $\mathrm{NO}_{2}$ concentrations help in obtaining high NOx removal.

When the exhaust was treated under 50\% load conditions using CPCR, the NOx removal efficiency was nearly unaffected up to an energy density of $80 \mathrm{~J} / \mathrm{L}$ at all temperatures, as shown in Figure 8. This was because the NO to $\mathrm{NO}_{2}$ conversion using plasma reactor was less up to an energy density of $80 \mathrm{~J} / \mathrm{L}$. Under $50 \%$ load condition, the NO removal efficiency obtained using the plasma reactor alone was only $30 \%$ at $80 \mathrm{~J} / \mathrm{L}$ and $45 \%$ at $96 \mathrm{~J} / \mathrm{L}$ (see Figure 4) at room temperature. The corresponding NOx removal efficiency obtained in case of CPCR $100^{\circ} \mathrm{C}$, are $30 \%$ and $72 \%$, respectively. Similar trends were observed at temperatures 150 and $200^{\circ} \mathrm{C}$. The NOx removal efficiencies obtained at 150 and $200^{\circ} \mathrm{C}$ using CPCR were 82 and $88 \%$, respectively.

The NOx removal efficiencies obtained under $50 \%$ load conditions were lesser than those under no-load conditions because of high initial NO concentrations. Figure 9 compares the NOx removal efficiencies under load and no-load conditions at an exhaust temperature of $150^{\circ} \mathrm{C}$. Under no-load conditions, it was found that at less energy input, NOx removals achieved were high compared to those under load conditions. For example, at an energy input of $70 \mathrm{~J} / \mathrm{L}$, the NOx removal under load conditions was only $43 \%$ as against $88 \%$ under no-load conditions. At maximum energy input of $96 \mathrm{~J} / \mathrm{L}$, the respective NOx removal efficiencies under no-load and 50\% load conditions achieved became 90 and $82 \%$, respectively.

\subsection{UNFILTERED (RAW) EXHAUST TREATMENT}

In this case, all experiments were carried out at room temperature under no load condition.

\subsubsection{PLASMA REACTOR (PR)}

Figure 10 gives the variation of NOx removal efficiency with respect to energy density. The NOx removal efficiency increases with increasing energy density [1, 19]. Further, comparing with Figure 2, at a given energy density, NOx removal efficiency was higher with plasma treating raw exhaust than that with treating filtered exhaust

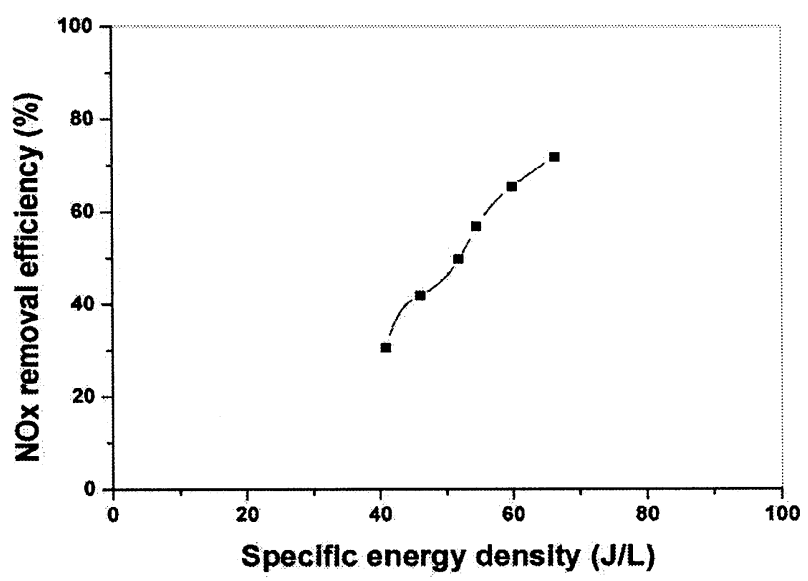

Figure 10. NOx removal efficiency in case of plasma treating unfiltered (raw) exhaust at room temperature under no load condition. 


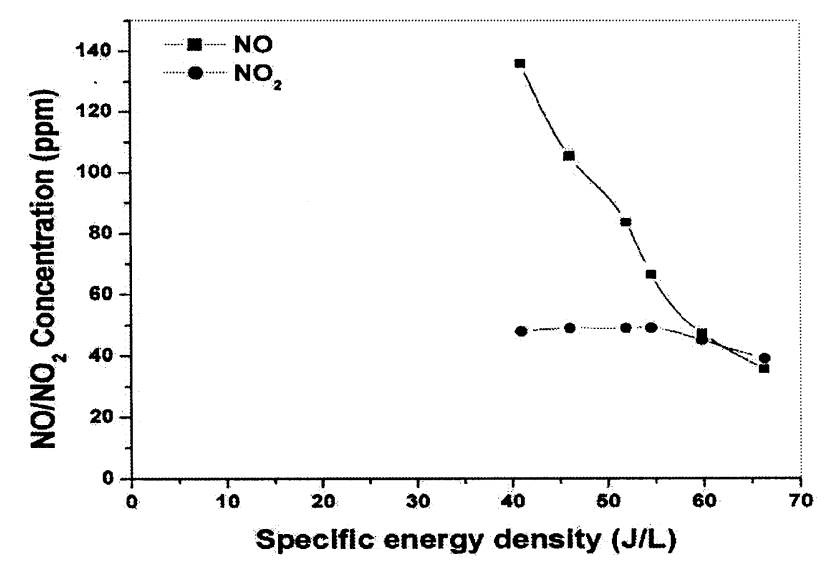

Figure 11. $\mathrm{NO}$ and $\mathrm{NO}_{2}$ concentrations obtained using plasma reactor treating raw exhaust at room temperature under no load condition.

(ex: at $66 \mathrm{~J} / \mathrm{L}$, raw exhaust plasma treatment gives $\mathrm{NOx}$ removal efficiency of $71 \%$, while it was only $45 \%$ with filtered exhaust plasma treatment). Further, in contrast to Figure 7, in raw exhaust treatment the $\mathrm{NO}_{2}$ concentration remains almost constant and $\mathrm{NO}$ concentration decreases with increasing energy density as shown in Figure 11. This can be due to the following reaction pathways:

In the presence of soot, the key radicals $(\mathrm{O} / \mathrm{OH})$ responsible for $\mathrm{NO}-\mathrm{NO}_{2}$ conversion and hydrocarbon oxidation are getting depleted by reacting with carbonaceous soot and as a result, the reactions (10) to (22) (section 3.1.1) are less probable. Hence, $\mathrm{NO}_{2}$ formation is affected. The partly converted $\mathrm{NO}_{2}$ reacts with soot by the following reaction [2]:

$\mathrm{NO}_{2}+$ Soot $\rightarrow \mathrm{CO}+\mathrm{CO}_{2}+\mathrm{N}_{2}+\mathrm{H}_{2} \mathrm{O}+\mathrm{NO}$

As a result, $\mathrm{NO}_{2}$ concentration will remain almost constant. Further, NO may be reduced to $\mathrm{N}_{2}$ as the reactions 1 and 2 (section 3.1.1) appear to be more probabilistic in the depleted $\mathrm{O}$ and $\mathrm{OH}$ environment. Therefore, total NOx is reduced to a value much less than that observed in filtered exhaust case [3, 20,21, 22].

\subsubsection{ADSORBENT REACTOR (AR)}

Studies were conducted using three commercial adsorbents namely, activated charcoal, MS-13X and activated alumina. The $\mathrm{NO}_{\mathrm{x}}$ removal efficiency with all the three adsorbents is shown in Figure 12. All the adsorbents show a marginal saturation effect after 30 minutes of use. The $\mathrm{NO}_{2}$ molecules having a larger molecular weight compared to NO molecules show a higher degree of adsorption [12]. The NO molecules show a lower degree of adsorption in case of all the three adsorbents. Further, activated charcoal exhibits superior adsorption property compared to other two adsorbents because of its large internal surface area.

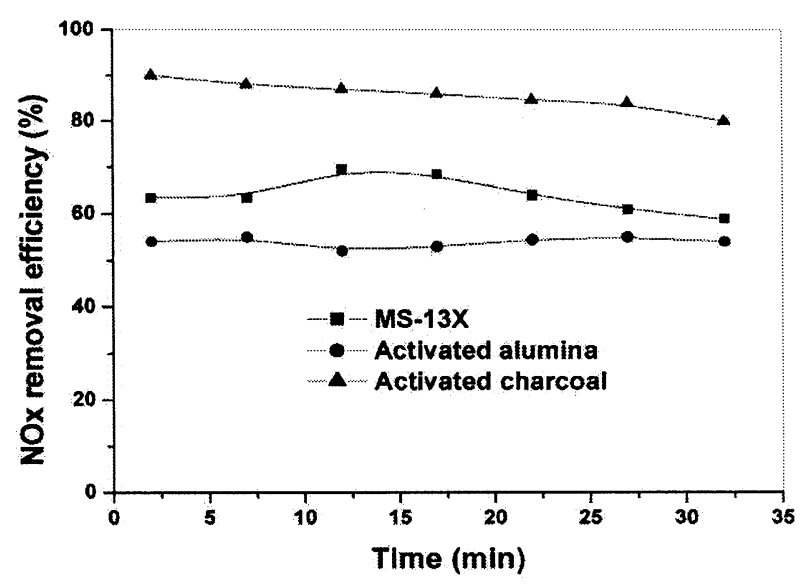

Figure 12. NOx removal efficiency using adsorbents at room temperature under no load condition.

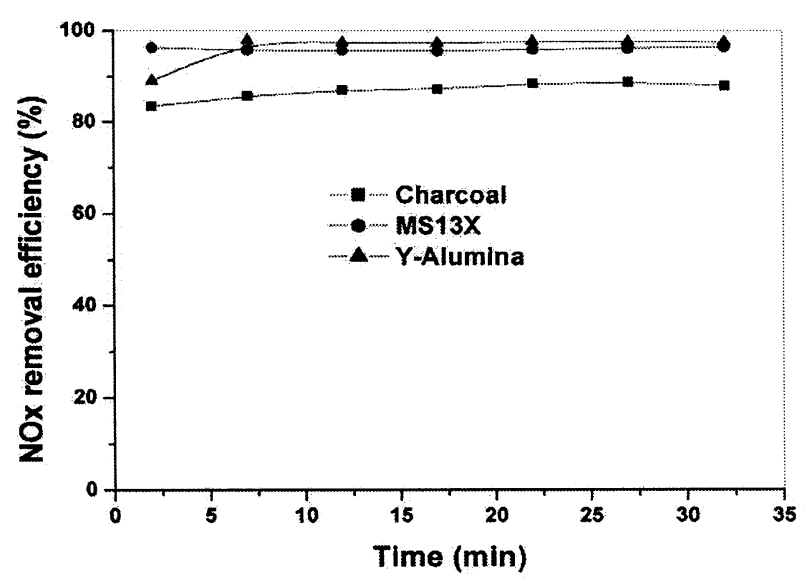

Figure 13. NOx removal efficiency in case of plasma-associated adsorption at room temperature under no load condition.

\subsubsection{CASCADED PLASMA-ADSORBENT REACTOR (CPAR)}

The adsorbent reactor packed with adsorbent beads was placed after the plasma reactor. It should be noted that in all the experiments the plasma reactor was operated at a constant discharge energy density of $60 \mathrm{~J} / \mathrm{L}$ corresponding to a voltage of $22 \mathrm{kV}$.

Figure 13 shows time dependent NOx removal efficiency for the three adsorbents associated by plasma. For a given adsorbent, the plasma-associated adsorption exhibits superior NOx removal characteristics compared to the individual processes- plasma/adsorption [8, 14]. At any given time, cascaded plasma-adsorbent reactor (any adsorbent), exhibits very high NOx removal (96\%). Owing to high NOx removal characteristic $(71 \%)$ of plasma treating raw exhaust, the exhaust entering an adsorbent contains lesser concentration of $\mathrm{NO}$ and $\mathrm{NO}_{2}$ molecules, as a result the type of adsorbent plays a little effect on NOx removal. Hence, cascaded plasma-adsorbent reactor configuration gives almost same NOx removal efficiency irrespective of type of adsorbent used. 


\section{CONCLUSIONS}

STUDIES were conducted on filtered and unfiltered (raw) stationary diesel engine exhaust using different aftertreatment techniques involving a combination of plasma, catalyst and adsorbents. The major inferences drawn from this work are summarized as below:

Presence of carbonaceous soot in the diesel engine raw exhaust enhances NOx removal capability of a plasma process. It directly reacts with $\mathrm{NO}_{2}$ and decreases the $\mathrm{NOx}$ concentration. In the filtered exhaust treatment, cascaded plasma-catalytic reactor performed better than catalytic reactor $\left(\mathrm{V}_{2} \mathrm{O}_{5}\right)$ alone for temperatures below $200{ }^{\circ} \mathrm{C}$. In case of cascaded plasma-catalytic reactor, at an energy density of $60 \mathrm{~J} / \mathrm{L}$, at which concentrations of $\mathrm{NO}$ and $\mathrm{NO}_{2}$ become equal, a very high NOx removal efficiency was observed. The activated charcoal exhibits a superior NOx adsorption property compared to MS-13X and activated alumina. For a given adsorbent, the plasma-associated adsorption exhibits superior NOx removal characteristics compared to the individual processes. The plasma-associated adsorption technique, exhibiting a very high NOx removal, can be a viable alternative aftertreatment technique, to plasma assisted selective catalytic technique. The authors are currently developing a prototype of hybrid plasma-adsorbent system for NO removal in engine exhausts.

\section{ACKNOWLEDGMENTS}

The authors wish to thank M/s Zeolites, India, for supply of adsorbent samples. This research was partially financed by University Grants Commission, India, under the Science and Technology Infrastructure Development Programme (COSIST/ASIST, 2001-05).

\section{REFERENCES}

[1] R. Hackam and H. Akiyama, "Air Pollution Control by Electrical Discharges", IEEE Trans. Dielectr. Electr. Insul., Vol 7, pp. 654-683, 2000.

[2] S. E. Thomas, A. R. Martin, D. Raybone, J. T. Shawcross, N. K. N. Beech and J. C. Whitehead, "Non Thermal Plasma Aftertreatment of Particulates, SAE 2000-01-1926, 2000.

[3] J. O. Chae, "Non Thermal Plasma for Diesel Exhaust Treatment", J. Electrostatics, Vol. 57, pp. 251-262, 2003.

[4] K. Fujii, M. Higashi and N. Suzuki, "Simultaneous Removal of $\mathrm{NO}_{\mathrm{x}}, \mathrm{CO}_{\mathrm{x}}, \mathrm{SO}_{\mathrm{x}}$ and Soot in Diesel Engine Exhaust", NonThermal Plasma Techniques for Pollution Control, NATO Series, Part-A, Ed: Penetrante and Schultheis, pp. 257-279, 1992.

[5] B. M. Penetrante, R. M. Brusasco, B. T. Merritt, and G. E. Vogtlin, "Environmental Applications of Low- temperature Plasmas", Pure Appl. Chem., 71, pp. 1829-1835, 1999.

[6] J. Hoard, "Plasma Catalysis for Diesel Exhaust Treatment: Current State of Art", Soc. Automotive Eng., 2001-01-0185, 2001.

[7] T. Yamamoto, M. Okubo, and T. Kuroki, "Non Thermal Plasma Desorption for NOx Control", Trans. Inst. Fluid Flow Machinery, No.107, pp. 111-120, 2000.

[8] M. Okubo, G. Tanioka, T. Kuroki and T. Yamamoto, "NOx Concentration Using Adsorption and Non-thermal Plasma Desorption", IEEE Trans. Indus. Appl., Vol.38, pp. 1196-1203, 2002.
[9] T. Yamamoto, M. Okubo, K. Nagaoka and T. Hayakawa, "Simultaneous Removal of NOx and SOx in Flue Gas Emission Using Plasma-chemical Hybrid Process", IEEE IAS Annu. Meet, pp. 641-648, 2000.

[10] T. Oda, T. Kato, T. Takahasi and K. Shimizu, "Nitric Oxide Decomposition in Air by Using Non-thermal Plasma Process with Additives and Catalysts", IEEE IAS Annu. Meet, Vol. 3, pp. 1803-1807, 1996.

[11] T. Shimizu, T. Hirano and T. Oda, "Effect of Water Vapour and Hydrocarbon in Removing NOx by Using Non Thermal Plasma and Catalysts", IEEE Trans. Ind. Appl., Vol. 37, pp. 464-471, 2001.

[12] B. S. Rajanikanth, A. D. Srinivasan and A. Nandiny, "A Cascaded Discharge Plasma Adsorbent Technique for Engine Exhaust Treatment", Plasma Sci. Techn., Vol. 5, pp. 1825-1833, 2003.

[13] G. Sathiamoorthy, S. Kalyana, W. C. Finney, R. J. Clark and B. R. Locke, "Chemical Reaction Kinetics and Reactor Modeling of NOx Removal in a Pulsed Streamer Corona Discharge Reactor", Indus. Eng. Chem. Research, Vol. 38, pp. 1844-1855, 1999.

[14] A. R. Martin, J. T. Shawcross and J. C. Whitehead, "Modelling of Non Thermal Plasma After Treatment of Exhaust Gas Streams", J. Phys. D: Appl. Phys., Vol. 37, pp. 42-49, 2004.

[15] B. M. Penetrante, M. C. Hsioa and B. T. Merritt, "Comparison of Electrical Discharge Technique for Non-thermal Plasma Processing of $\mathrm{NO}$ in $\mathrm{N}_{2}$ ”, IEEE Trans. Plasma Sci., Vol. 23, pp. 680-687, 1995

[16] Y. S. Mok and I. S. Nam, "Role of Organic Chemical Additives in Pulsed Corona Discharge Process for Conversion of NO", J. Chem. Eng. Japan, Vol. 31, pp. 391-397, 1998.

[17] B. S. Rajanikanth and S. Rout, "Studies on Nitric Oxide Removal in Simulated Gas Compositions under PlasmaDielectric/Catalytic Discharges", Fuel Processing Technology, Vol. 74, pp. 177-195, 2001.

[18] F. Luck and J. Roiron, "Selective Catalytic Reduction of NOx Emitted by Nitric Acid Plants", Catalysis Today, Vol. 4, pp. 205-218, 1989.

[19] B. M. Penetrante, R.M. Brusasco, B. T. Merritt, W. J. Pitz and G. E. Vogltin, "Feasibility of Plasma Aftertreatment for Simultaneous Control of NOx and Particulates", SAE, pp. 2056-2061, 1999.

[20] A. Harano, M. Sadakata and S. Masayuki, "Soot Oxidation in a Silent Discharge", J. Chem. Engg, Japan, Vol. 24, pp. 100-106, 1991.

[21] A. Harano, K. Murata, K. Takamizawa and M. Sadakata, "Oxidation of Carbonaceous Particles in Silent Discharge Reactor", J. Chem. Engg, Japan, Vol. 31, pp. 700-705, 1998.

[22] Y. Matsui, M. Hashimoto, A. Sakaguchi, K. Takashima and A. Mizuno, "Oxidation of Carbon Soot Layer using Pulsed Discharge Plasma", SAE meeting, 01FL-441, 2001.

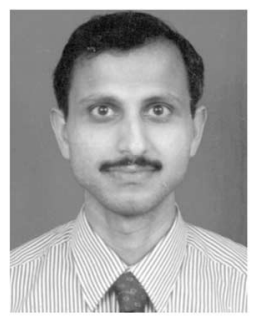

B. S. Rajanikanth (S'93-M'95-SM'00) was born in Bangalore, India on 1 May 1965 . He received the B.E. degree in electrical engineering from Bangalore University in 1987 and the M.S. and Ph.D. degrees in HV engineering from the Indian Institute of Science, Bangalore, in 1990 and 1993, respectively. He was a post-doctoral research fellow at Toyohashi University of Technology, Japan, from 1994 to 1996 . He then joined Kirloskar Systems Limited, Bangalore, where he chaired the R\&D department. He was a visiting researcher at Tokyo Metropolitan University during the winter of 1996 and a visiting Professor at Osaka Metropolitan University during the summer of 2001. He is currently an Associate Professor in the HV Engineering department, IISc, Bangalore. His research interests are mainly in the applications of high voltages for air pollution control and modeling of electrical characteristics of precipitators. He has several journal publications and international conferences. One of his papers on air pollution control has earned an IEEE committee prize Paper Award in 1998. 


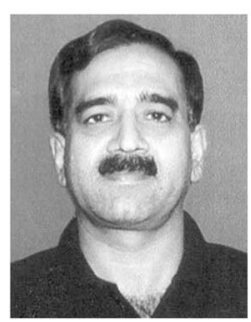

A. D. Srinivasan was born in Mysore, India in 1961. He received the B.Eng. degree and Post graduate diploma in system analysis from the University of Mysore in 1984 and 1990, respectively. He received the Masters degree from the Indian Institute of Science, Bangalore in 1996. He taught at the $\mathrm{Na}$ tional Institute of Engg., Mysore from 1984 to 1985 and subsequently worked at $\mathrm{Kir}$ loskar Electric Company Ltd, Mysore from 1985 to 1987 . He is currently an Assistant Professor in the Electrical and Electronics Engg. Department, S.J. College of Engg., Mysore. He has 17 years of teaching experience and is now pursuing a Ph.D. degree in the Department of HV Engg. at IISc. His research interests are applications of $\mathrm{HV}$ and power electronics in air pollution control.

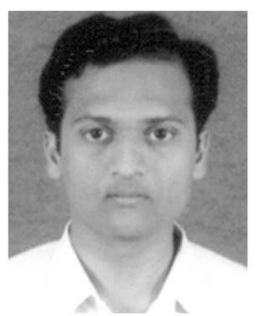

V. Ravi was born in 1976 at Chitradurga, Karnataka, India. He received the Master degree in physics from Mangalore University in 1998. He obtained the M.S. and Ph.D. degrees at the Dept. of HV Engineering, Indian Institute of Science (IISc), Bangalore in 2001 and 2003, respectively. He was an invited researcher at Cheju National University, South Korea during the summer of 2002. He was a Research Assistant in Materials Research Centre, IISc 1998-99 in the area of glass-ceramics. He has several journal publications. At present he is a Post Doctoral Fellow at INHA University, South Korea. His research interests are applications of low and high temperature plasmas. 